\title{
THE IMPACT OF THE NATIONAL POLICY ON EDUCATION (NPE) ON MULTILINGUAL PROFICIENCY IN NIGERIA
}

\author{
Udoye, Ifeoma Emmanuela
}

Anambra State University, Uli, Nigeria.

\begin{abstract}
About 450 languages are spoken in Nigeria with Hausa, Igbo and Yoruba as the major languages. In order to assign functional roles to the multiplicity of languages, the Federal Government promulgated the National Policy on Education (henceforth NPE) in 1977 stipulated that every Nigerian child must be proficient in his mother tongue and in a major Nigerian language. At the secondary level, it is expected that every child should be bilingual in two Nigerian languages. Thirty six years later, the impact of the policy on the language education of Nigerian pupils was assessed. Data were collected using questionnaire and interview methods. Findings revealed that the primary aim of the NPE has not been achieved. Based on the findings, the recommendation made include the organization of intensive workshop sessions for language teachers to expose them to the modern techniques for attaining bilingualism through effective training.
\end{abstract}

KEYWORDS: National Policy, Education, Language, Nigeria

\section{INTRODUCTION}

Language has become one of the greatest issues of discussion today: from its seemingly unnoticeable emergence in the Garden of Eden, according to the Bible, to a widely received attention in Nigeria in the middle of the nineteenth century. Language is recognized as the major tool for communicating social, cultural and intellectual capacity of a given society/individuals. The Christian missionaries were the first to recognize the importance of indigenous languages in the spreading of the gospel. Subsequently, UNESCO began advocacy for the use of indigenous languages in 1953 with the publication of The Use of Vernacular Languages in Education. The Colloquium made several important recommendations to African governments, including:

(a) Use and teaching of African language in educational institutions in order to "ensure harmonious and balanced training of African Youth";

(b) Delivery of literacy campaigns for the masses in African languages;

(c) Publication and media dissemination of literary and scientific works and development of information in African languages; and,

(d) Collaboration in teaching and research in African languages (Amoda, 1998:209).

Later, efforts at creating awareness about the many languages in Nigeria received a boost from the Federal Government in 1977 through the formulation of the National Policy on Education 1977 (henceforth NPE revised 1986 and 2004) with the aim of making every Nigerian Child bilingual in indigenous languages. The NPE encourages the early acquisition of Nigerian languages at pre-primary school level. Chumbow (1990) opined that a child learns better and 
develops faster if he is taught in his native language. Similarly, Obidlor (1990) emphasized that for a child to learn basic concepts easily in order to make significant progress in life and at school, the language to use is the indigenous language. Jettisoning the first language as a medium of education would contribute to emotional, mental and social underdevelopment (Okonkwo, 1986). This is because indigenous languages are of great importance in the teaching and learning of native intelligence and wisdom which are beneficial to future development in terms of curiosity, manipulative skills, spontaneous flexibility, initiative, and manual dexterity which fosters national pride, and identity (Amfani, 2009). It also preserves and promotes indigenous culture (Okuyemi, 2013). Additionally, Fafunwa, et al (1989) observed that children taught mathematics and other curriculum subjects using an African language as medium of instruction over a six year experimental period significantly out- performed their control group peers in all related aspects of the school curriculum. This is in accordance with McHugh's (1981) observation who noted that the use of indigenous languages as a medium of instruction enhances continuity in the child's learning process and it maximizes the child's intellectual development. The materialization of the NPE represents high promises for the Nigerian populace. It is anticipated that the National Policy on Education would encourage the massive use of every language in Nigeria and thereby drastically minimize the loss of any indigenous language. The NPE, by implication, encouraged the development of all languages such that:

- All Nigerian children will receive initial education in the language of the immediate community. The implication is that all grassroot languages can now become the medium of education for nursery and lower primary school children and are ipso facto eligible for development by linguists to enable them to perform their new roles.

- Each Nigerian child will be bilingual in Nigerian languages. For example, a child whose mother - tongue is Ikwo is expected to also learn Standard Igbo which might be an L2. In addition he will be expected to learn Hausa or Yoruba also as L2. But a child who already speaks Standard Igbo as L1 is required to learn Hausa or Yoruba as L2 to satisfy the requirements of NPE

- English will continue to enjoy the pride of place in the educational system. It will be taught on the secondary level and throughout tertiary education since it will be the language of bureaucracy at all levels of government.

The NPE (2004) stipulated that secondary school students must be exposed to two Nigerian languages and English and French, thereby making the Nigerian children quadrilinguals: English is the medium of instruction at the secondary and university levels; French is studied as a foreign language. A situation where our school system has to produce quadrilinguals continues to pose many problems. The policy was executed with vigour in the eighties: some states in northern Nigeria employed National Certificate in Education (NCE) teachers of Igbo and Yoruba to teach Igbo and Yoruba in the schools. The states in the South West and South East could not correspondingly find teachers to teach Hausa. Again the Federal Government established Federal Government Colleges which they call "unity schools" so that bilinguals would be produced. The project failed at both Federal and state government levels.

Anagbogu (1999)observed that the curriculum for the teaching of the three languages at secondary school level is saddled with a lot of problems and confusion. Anagbogu (1999) showed that students learning one major and minor language do not exhibit mastery of the L2 
Published by European Centre for Research Training and Development UK (www.eajournals.org)

they are taught in schools. In light of the submission made above, this paper examines the impact of the NPE in bilingual proficiency among secondary school children in Anambra state.

\section{Statement of the Problem}

Nigeria has the highest number of languages in sub-sahara Africa. According to Kame (2012) , Nigeria is the leader of linguistic diversity by the sheer number of languages. Out of the 13 countries that make up the sub-Saharan group, Nigeria has 514 languages, while Cameroon has 278, Congo DRC 215, Chad 131, Tanzania 128, Ghana 79, Cote d 'Ivoire 78, Kenya 69, Burkina Faso 68, Central African Republic 71, Congo Brazzaville 62, Mali 57, Benin 54 (Kame, 2012). Despite the number of languages credited to Nigeria, Paul, Simons and Fennig (2013) opined that only 22 of the languages are institutionalized, 80 developing, 358 are vigorously undergoing changes, 20 are endangered and 42 are gradually going into extinction. According to the figures above, it is expected that every Nigerian child should be bilingual.

The fact that Nigeria has the highest number of languages in West Africa that can be discussed from various standpoints is not in dispute. The aim of this study is to determine how the NPE in terms of language teaching and learning has fared in the past 37 years. Specifically, the study was designed to determine the impact of NPE on multilingual proficiency of secondary school children in Anambra state, Nigeria.

\section{Research Questions}

The following research questions guided the study

1. How effective is the NPE on the teaching and learning of indigenous languages in Nigeria?

2. What is the performance of students based on the four language skills: speaking, listening, reading and writing

\section{METHOD}

Population: The target population consisted of students in secondary schools in Anambra state Nigeria. The secondary schools include 2 urban and 2 rural schools.

Sample: Purposive sampling was used a total of 208 students was used for the study.

Questionnaires: The questionnaire is based on the US language Proficiency Self Assessment by the Federal Bureau of Investigation. The instrument contained questions concerning proficiency in language. The respondents were asked to rank in the order of the level of proficiency and according to their degree. They were to rate the most proficient as very high extent, the next, high extent, very low extent and low extent. Below is adopted and modified model by the FBI Language Proficiency Self Assessment which will be used for the study:

Table 1: US language Proficiency Self Assessment Table by the Federal Bureau of Investigation 
Published by European Centre for Research Training and Development UK (www.eajournals.org)

\begin{tabular}{|c|c|c|c|c|}
\hline Level & Speaking & Listening & Reading & Writing \\
\hline 0 & $\begin{array}{l}\text { No Proficiency: } \\
\text { Unable to function in } \\
\text { the spoken language }\end{array}$ & $\begin{array}{l}\text { No Proficiency: No } \\
\text { practical } \\
\text { understanding of the } \\
\text { spoken language. }\end{array}$ & $\begin{array}{l}\text { No Proficiency: No } \\
\text { practical ability to } \\
\text { read the language. }\end{array}$ & $\begin{array}{l}\text { No Proficiency: } \\
\text { No functional } \\
\text { writing ability. }\end{array}$ \\
\hline $0+$ & $\begin{array}{l}\text { Memorized } \\
\text { Proficiency: Able to } \\
\text { satisfy immediate } \\
\text { needs using rehearsed } \\
\text { utterances. }\end{array}$ & $\begin{array}{l}\text { Memorized } \\
\text { Proficiency: } \\
\text { Sufficient } \\
\text { comprehension to } \\
\text { understand a number } \\
\text { of memorized } \\
\text { utterances in areas } \\
\text { of immediate needs. }\end{array}$ & $\begin{array}{l}\text { Memorized } \\
\text { Proficiency: Can } \\
\text { recognize all the } \\
\text { letters in the printed } \\
\text { version of an } \\
\text { alphabetic system } \\
\text { and high- frequency } \\
\text { elements of a } \\
\text { syllabary or a } \\
\text { character system. }\end{array}$ & $\begin{array}{l}\text { Memorized } \\
\text { Proficiency: } \\
\text { Writes using } \\
\text { memorized } \\
\text { material and set } \\
\text { expressions. }\end{array}$ \\
\hline 1 & $\begin{array}{l}\text { Elementary } \\
\text { Proficiency: Able to } \\
\text { satisfy minimum } \\
\text { courtesy } \\
\text { requirements and } \\
\text { maintain very simple } \\
\text { face-to-face } \\
\text { conversations on } \\
\text { familiar topics. }\end{array}$ & $\begin{array}{l}\text { Elementary } \\
\text { Proficiency: } \\
\text { Sufficient } \\
\text { comprehension to } \\
\text { understand } \\
\text { utterances about } \\
\text { basic survival needs } \\
\text { and minimum } \\
\text { courtesy and travel } \\
\text { requirements. }\end{array}$ & $\begin{array}{l}\text { Elementary } \\
\text { Proficiency: } \\
\text { Sufficient } \\
\text { comprehension to } \\
\text { read very simple } \\
\text { connected written } \\
\text { material in a form } \\
\text { equivalent to usual } \\
\text { printing or } \\
\text { typescript. }\end{array}$ & $\begin{array}{l}\text { Elementary } \\
\text { Proficiency: } \\
\text { Sufficient control } \\
\text { of the writing } \\
\text { system to meet } \\
\text { limited practical } \\
\text { needs. }\end{array}$ \\
\hline 2 & $\begin{array}{l}\text { Functionally Native } \\
\text { Proficiency: } \\
\text { Speaking proficiency } \\
\text { is functionally } \\
\text { equivalent to that of a } \\
\text { highly articulate, } \\
\text { well-educated native } \\
\text { speaker and reflects } \\
\text { the cultural standards } \\
\text { of the country where } \\
\text { the language is } \\
\text { natively spoken. }\end{array}$ & $\begin{array}{l}\text { Functionally Native } \\
\text { Proficiency: } \\
\text { Comprehension } \\
\text { equivalent to that of } \\
\text { an educated native } \\
\text { listener. }\end{array}$ & $\begin{array}{l}\text { Functionally Native } \\
\text { Proficiency: } \\
\text { Reading proficiency } \\
\text { is functionally } \\
\text { equivalent to that of } \\
\text { the well-educated } \\
\text { native reader. }\end{array}$ & $\begin{array}{l}\text { Advanced } \\
\text { Professional } \\
\text { Proficiency, Plus: } \\
\text { Able to write the } \\
\text { language precisely } \\
\text { and accurately in a } \\
\text { wide variety of } \\
\text { prose styles } \\
\text { pertinent to } \\
\text { professional/ } \\
\text { educational needs. }\end{array}$ \\
\hline
\end{tabular}

\section{RESULTS}

Results obtained from data analysis reveal that poor reading, writing, listening and speaking skills affect multilingual proficiency.

Table 2: Level 0 
Published by European Centre for Research Training and Development UK (www.eajournals.org)

\begin{tabular}{|c|c|c|c|c|c|}
\hline Languages & Level & Speaking & Listening & Reading & Writing \\
\hline $\begin{array}{l}\text { English } \\
\text { Igbo } \\
\text { French } \\
\text { Hausa } \\
\text { Yoruba } \\
\text { Other indigenous languages }\end{array}$ & $\begin{array}{l}\mathbf{0} \\
\mathbf{0} \\
\mathbf{0} \\
\mathbf{0} \\
\mathbf{0} \\
\mathbf{0}\end{array}$ & \begin{tabular}{ll}
\multicolumn{2}{l}{ Low extent } \\
Low extent \\
Very low \\
extent \\
Very low \\
extent \\
Very low \\
extent \\
Very low \\
extent
\end{tabular} & \begin{tabular}{ll}
\multicolumn{2}{l}{ Low extent } \\
Low extent \\
Very low \\
extent \\
Very low \\
extent \\
Very low \\
extent \\
Very low \\
extent
\end{tabular} & \begin{tabular}{ll}
\multicolumn{2}{l}{ Low extent } \\
Low extent \\
Very low \\
extent \\
Very \\
extent & \\
Very & low \\
extent & \\
Very & low \\
extent &
\end{tabular} & $\begin{array}{l}\text { Very low extent } \\
\text { Low extent } \\
\text { Very low extent } \\
\text { Very low extent } \\
\text { Very low extent } \\
\text { Very low extent }\end{array}$ \\
\hline
\end{tabular}

Table 2 above shows that the respondents ranked low in English and Igbo and ranked lowest in writing the English language. On the other hand, the respondents were graded very low in French, Hausa, Yoruba and other indigenous languages in all the communicative skills.

Table 3: Level 0+

\begin{tabular}{|c|c|c|c|c|c|}
\hline Languages & Level & Speaking & Listening & Reading & Writing \\
\hline $\begin{array}{l}\text { English } \\
\text { Igbo } \\
\text { French } \\
\text { Hausa } \\
\text { Yoruba } \\
\text { Other indigenous languages }\end{array}$ & $\begin{array}{l}\text { 0+ } \\
0+ \\
0+ \\
0+ \\
0+ \\
0+\end{array}$ & \begin{tabular}{ll}
\multicolumn{2}{l}{ High extent } \\
High extent \\
Very low \\
extent \\
Very low \\
extent \\
Very low \\
extent \\
Very low \\
extent
\end{tabular} & \begin{tabular}{ll}
\multicolumn{2}{l}{ High extent } \\
High extent \\
Very low \\
extent \\
Very low \\
extent \\
Very low \\
extent \\
Very low \\
extent
\end{tabular} & \begin{tabular}{ll}
\multicolumn{2}{l}{ High extent } \\
High extent \\
Very low \\
extent \\
Very & \\
extent & \\
Very & low \\
extent & \\
Very & low \\
extent &
\end{tabular} & $\begin{array}{l}\text { Very low extent } \\
\text { Low extent } \\
\text { Very low extent } \\
\text { Very low extent } \\
\text { Very low extent } \\
\text { Very low extent }\end{array}$ \\
\hline
\end{tabular}

Table 3 above shows that the respondents ranked high in the three communicative skills in English and Igbo and ranked lowest in writing English and Igbo languages. On the other hand, the respondents were graded very low in French, Hausa, Yoruba and other indigenous languages in all the communicative skills.

Table 4: Level 1

\begin{tabular}{|l|l|l|l|l|l|}
\hline Languages & Level & Speaking & Listening & Reading & Writing \\
\hline English & $\mathbf{1}$ & Low extent & Very low & Low extent & Very low extent \\
Igbo & $\mathbf{1}$ & Very high & extent & Low extent & Low extent \\
French & $\mathbf{1}$ & extent & High extent & Very low & Very low extent \\
Hausa & $\mathbf{1}$ & Very low & Very low & extent low low & Very low extent \\
Yoruba & $\mathbf{1}$ & extent & extent lery low extent \\
Other indigenous languages & $\mathbf{1}$ & & & Very low & Very low extent \\
\hline
\end{tabular}


Vol.4, No.3, pp.14-22, February 2016

Published by European Centre for Research Training and Development UK (www.eajournals.org)

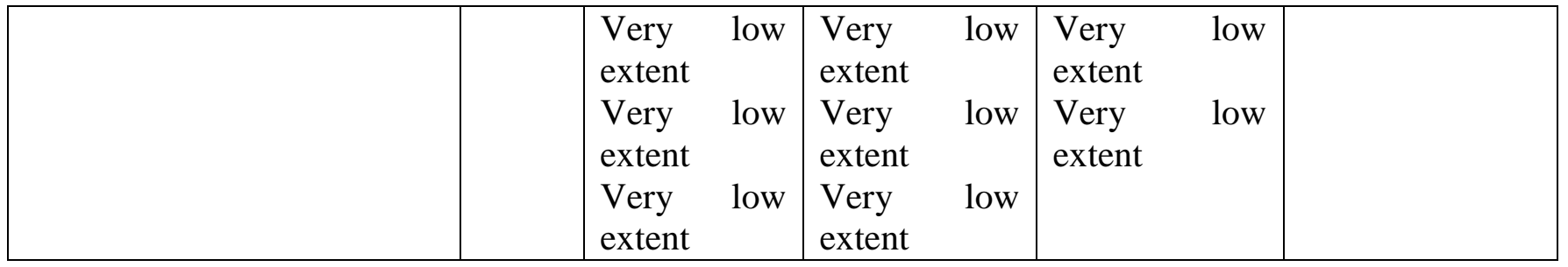

Table 4 above shows that the respondents ranked low in English, but performed better in Igbo indicates very high extent but ranked lowest in writing all the languages. However, the respondents were graded very low in French, Hausa, Yoruba and other indigenous languages in all the communicative skills.

Table 5: Level 2

\begin{tabular}{|c|c|c|c|c|c|}
\hline Languages & Level & Speaking & Listening & Reading & Writing \\
\hline $\begin{array}{l}\text { English } \\
\text { Igbo } \\
\text { French } \\
\text { Hausa } \\
\text { Yoruba } \\
\text { Other indigenous languages }\end{array}$ & $\begin{array}{l}2 \\
2 \\
2 \\
2 \\
2 \\
2\end{array}$ & \begin{tabular}{lr}
\multicolumn{2}{l}{ Low extent } \\
Low extent \\
Very low \\
extent \\
Very low \\
extent \\
Very low \\
extent \\
Very low \\
extent
\end{tabular} & \begin{tabular}{ll}
\multicolumn{2}{l}{ Low extent } \\
\multicolumn{2}{l}{ Low extent } \\
Very low \\
extent & \\
Very & low \\
extent & \\
Very & low \\
extent & \\
Very & low \\
extent &
\end{tabular} & \begin{tabular}{ll}
\multicolumn{2}{l}{ Low extent } \\
\multicolumn{2}{l}{ Low extent } \\
Very low \\
extent \\
Very & \\
extent & \\
Very & low \\
extent & \\
Very & low \\
extent &
\end{tabular} & $\begin{array}{l}\text { Very low extent } \\
\text { Low extent } \\
\text { Very low extent } \\
\text { Very low extent } \\
\text { Very low extent } \\
\text { Very low extent }\end{array}$ \\
\hline
\end{tabular}

Table 5 above shows that the respondents ranked low in English and Igbo. On the other hand, the respondents were graded very low in French, Hausa, Yoruba and other indigenous languages in all the communicative skills.

\section{DISCUSSION}

From the above tables 2,3,4,5, it is clear that students performed badly in speaking particularly in indigenous languages mainly in the two major languages: Hausa and Yoruba languages. This contradicts the vision of the NPE (1977, 1986 and 2004) whose aim was to make every Nigerian Child bilingual in indigenous languages. This will also affect the development of native intelligence and wisdom which are beneficial to future development in terms of curiosity, manipulative skills, spontaneous flexibility, initiative, speaking skills and manual dexterity which fosters national pride, and identity (Amfani, 2009). This is unfortunate because speaking is key to communication. This is in line with Burns and Joyce (1997) who observe that a skilled speaker should be able to manage discrete elements such as turn taking, rephrasing, providing feed back or redirecting. Speaking involves a repertoire of psychological and interpersonal features in terms of language production (syntax, semantics and speech process). The findings give credence to Jowitt (1991) who notes that the quality of both spoken and written language has been deteriorating over a long period. Richards and Rodgers (1986) believe that social interaction activities such as conversation, discussion, dialogue, role -plays and debates increase a student's language proficiency. It is surprising that students find it 
Published by European Centre for Research Training and Development UK (www.eajournals.org)

difficult to listen effectively. Ralph and Stevens (1957) observe that students spend $46 \%$ of their time listening to the teachings of the teacher, $30 \%$ in speaking, $16 \%$ in reading and $9 \%$ in writing in our daily communication. It is therefore pertinent that great attention should be paid to listening than to speaking.

However, it is surprising that students ranked below expectation because the importance of reading for effective communication cannot be overemphasized for reading involves phonological, syntactic and semantic skill managed by cognitive process. Reading helps to master the vocabulary. Brown (1987) emphasized that differences about a reader relies solely on the graphics and symbols that add more to memory capacity.

Finally, writing begins at school. Tribble (1996) identified four stages of writing which are composing, drafting, revising and editing. This is in line with NPE whose aim is to inculcate the ability to communicate effectively in the mother tongue in the written form through creative writing such as: short stories, poems, compositions, etc. among school children. Ohiri-Aniche (1990) in her study shows that secondary school students prefer English and French to indigenous languages even though their preference has not been positively reflected in their examination performance. This fact gives credence to Okonkwo (1986) who opined that abandoning the first language as a medium of education would contribute to emotional, mental social underdevelopment, and poor performance in all the other subjects . Similarly, Anagbogu (1999) observed that students who are taught major and minor languages at the same time, lack the mastery of the L2 they are taught in schools. Thus, the School Certificate results as shown in table 6 below is a summary of students' performance in WAEC which further shows that students fail every year in indigenous languages:

TABLE 6: WAEC NON-CREDIT PASS + FAIL RATES: 2002, 2003, 2004

\begin{tabular}{|l|c|c|c|c|}
\hline \multicolumn{1}{|c|}{ Languages } & $\begin{array}{c}\text { Total No. Sat } \\
\text { (A) }\end{array}$ & $\begin{array}{c}\text { Non-Credit } \\
\text { Pass (B) }\end{array}$ & $\begin{array}{c}\text { Fail } \\
\text { (C) }\end{array}$ & $\begin{array}{c}\text { Percentage } \\
\text { (B + C) }\end{array}$ \\
\hline Arabic & 16,633 & 3,761 & 6,800 & 63.49 \\
\hline English & $2,672,363$ & 875,801 & $1,025,861$ & 71.16 \\
\hline French & 3,916 & 565 & 1,332 & 48.44 \\
\hline Hausa & 342,541 & 95,857 & 80,797 & 51.57 \\
\hline Igbo & 381,306 & 66,548 & 66,160 & 34.80 \\
\hline Yoruba & 861,181 & 386,181 & 172,440 & 64.94 \\
\hline
\end{tabular}

Source: Computed from West African Examinations Council May/June 2005.

TABLE 7: WAEC NON-CREDIT PASS + FAIL RATES: 2005, 2006, 2007

\begin{tabular}{|l|c|c|c|c|}
\hline \multicolumn{1}{|c|}{ Languages } & $\begin{array}{c}\text { Total No. Sat } \\
\text { (A) }\end{array}$ & $\begin{array}{c}\text { Non-Credit } \\
\text { Pass (B) }\end{array}$ & $\begin{array}{c}\text { Fail } \\
\text { (C) }\end{array}$ & $\begin{array}{c}\text { Percentage } \\
\text { (B + C) }\end{array}$ \\
\hline Arabic & 30,098 & 10,375 & 11,756 & 73.52 \\
\hline English & $3,471,423$ & 814,518 & $2,345,985$ & 91.04 \\
\hline French & 6,997 & 1,714 & 3,017 & 67.67 \\
\hline Hausa & 542,577 & 147,279 & 323,465 & 86.76 \\
\hline Igbo & 508,498 & 140,899 & 252,746 & 77.41 \\
\hline Yoruba & 932,167 & 152,573 & 487,782 & 61.09 \\
\hline
\end{tabular}

Source: Computed from West African Examinations Council (WAEC), May/June 2008. 
Published by European Centre for Research Training and Development UK (www.eajournals.org)

From the above statistics, it is obvious that despite the students' preferences, they still performed badly in English and French and even in their indigenous languages. The expectation of Nigerians that the NPE would perform miracles was dashed to the board.

\section{RECOMMENDATIONS}

Based on the findings of the study, it is hereby recommended that:

- Adequate and sustained publicity among Nigerian students in post primary schools should be made by school authorities in order to increase awareness of the benefits of speaking accurately many indigenous languages which enhances the teaching and learning of subjects. This publicity must be made in collaboration with the government and language experts to reach the grass root level

- Efforts must be made to increase students language proficiency since young people are attracted more by what they can experience than mere rhetoric, it is necessary that emphasis on listening and reading should be layered among secondary school students and the teaching of indigenous languages should be manned by well trained personnel who can provide modern linguistic services. The encounter with seasoned language experts in schools at a tender age could positively influence the disposition of the children toward language skills acquisition.

- Accomplished linguists both academics and practitioners should take up responsibility in organizing essay writing competition and sponsoring mass media policy programs in writing skills. Public awareness of language is very vital if the profession is to attract some of the best brains in the country who can meet the challenges of languages in the $21^{\text {st }}$ century in Nigeria.

\section{CONCLUSION}

In conclusion, this paper has highlighted the pivotal challenges faced by Nigerian students. To contend with these problems, publishers, teachers and the government need to support the tenets of language teaching and learning by giving awards to deserving students, offering automatic employment to bilinguals in different federal government agencies. Until then, literacy in the languages will continue to face hardships.

\section{REFERENCES}

Anagbogu, P (1999). "Language planning in Nigeria: a critical review". Unizik Journal of Humanities vol. 1, no1

Amfani, A.H (2009). Indigenous languages and development in Nigeria. A paper delivered at a public lecture held at the Institute for Nigerian languages, University of Nigeria, Aba

Bae J and L. F. Bachman, (1998). "A latent variable approach to listening and reading: testing factorial invariance across two groups of children in the korean/English two-way immersion program,"

Language Testing, vol. 15, no. 3, pp. 380-414. 
Burns A. and Joyce H (1997). "Focus on speaking" Sydney. National Center for English language Teaching.

Brown, J (1987). “Listening-ubiquitous yet obscure,". Journal of the International Listening Association, vol. 1, pp. 3-14.

Fafunwa, A.B, Macaulay, T. I., Sokoya, J. A.F. (eds.) (1989). Education in the Mother Tongue: The Ife Primary Education Research Project, Ibadan: University Press Limited.

Floyed, J (1985). Listening a Practical Approach, Scott Foreswan and Company, Glenview, Ill, USA.

Jowitt, X (1991). Nigerian English usage an introduction. Longman Ikeja: Nigeria

Hunsaker, R.A (1990). Understanding and Developing the Skills of Oral Communication: Speaking and Listening. J. Morton Press, Englewood, Colo, USA, 2nd edition.

James, C.A (1985). "The testing of proficiency in listening comprehension: guiding for teaching," In a meeting the call for excellence in the foreign language classroom and selected papers from the Central States Conference on the Teaching of Foreign Languages.

National Policy on Education (2004). Lagos: Federal Government of Nigeria Press.

Ohiri-Aniche, C. (1990). Language use and preferences among selected Junior Secondary School Students in Nigeria. Journal of Studies in Curriculum, Vol. 1, No 2, September, pp 106-114.

Ralph G.N and L. S. Stevens (1957). Are You Listening? McGraw-Hill, New York, NY, USA. Rost, M (1994). Introducing Listening. Renguin Group, London, UK.

Yalcinkaya, N. B. Muluk, and S. Sahin, (2009). "Effects of listening ability on speaking, writing and reading skills of children who were suspected of auditory processing difficulty," International Journal of Pediatric Otorhinolaryngology, vol. 73, no. 8, pp. 1137-1142, 2009.

West African Examination Council Statistics, (2004, 2005). Lagos.

West African Examinations Council Statistics, (2005, 2008).Lagos. 